\title{
TDP1 wt Allele
}

National Cancer Institute

\section{Source}

National Cancer Institute. TDP1 wt Allele. NCI Thesaurus. Code C105095.

Human TDP1 wild-type allele is located in the vicinity of $14 q 32.11$ and is approximately 90 $\mathrm{kb}$ in length. This allele, which encodes tyrosyl-DNA phosphodiesterase 1 protein, is involved in DNA repair. Mutation of the gene is associated with spinocerebellar ataxia autosomal recessive with axonal neuropathy. 